\title{
JUURNAL.RU
}

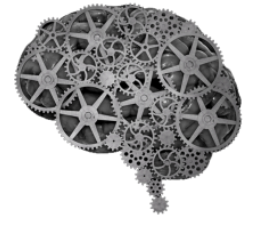

COMPANY GROUP "INTELLEKT"

\author{
Лю Юйхан, Слепнев М.А. \\ МГСУ \\ Москва, Россия
}

doi: 10.18411/1j2016-5-2-15

\section{Плотность населения и устойчивость природных экосистем в г. Чэнду (КНДР)}

Экологические проблемы крупных городов, связаны с высокой концентрацией населения на относительно небольших территориях. При этом распределение плотности населения в пределах города различно, что определяется социальными, экономическими и природными факторами [1]. Исследования, посвященные формированию природного каркаса города, играющего важную роль в формировании устойчивого развития урбанизированных территорий, показывают, что их экосистемы зависят от рекреационной нагрузки, воспринимаемой ими [2,3,4]. Что бы сохранить природные экосистемы проводится экологический мониторинг этих территорий, и разрабатываются различные законодательные акты и нормативы, эффективность которых проверяется временем [5,6]. В работе поставлена цель проанализировать распределение плотности населения на территории г. Чэнду, ценра провинции Сычуань, расположенной в юго-западном Китае. Это крупнейший город занимающий пятое место по численности населения в Китае, площадь 12390 км², с численностью населения около 14 млн. человек. В центре города площадь 465км², с численностью населения около 5,34 млн. 


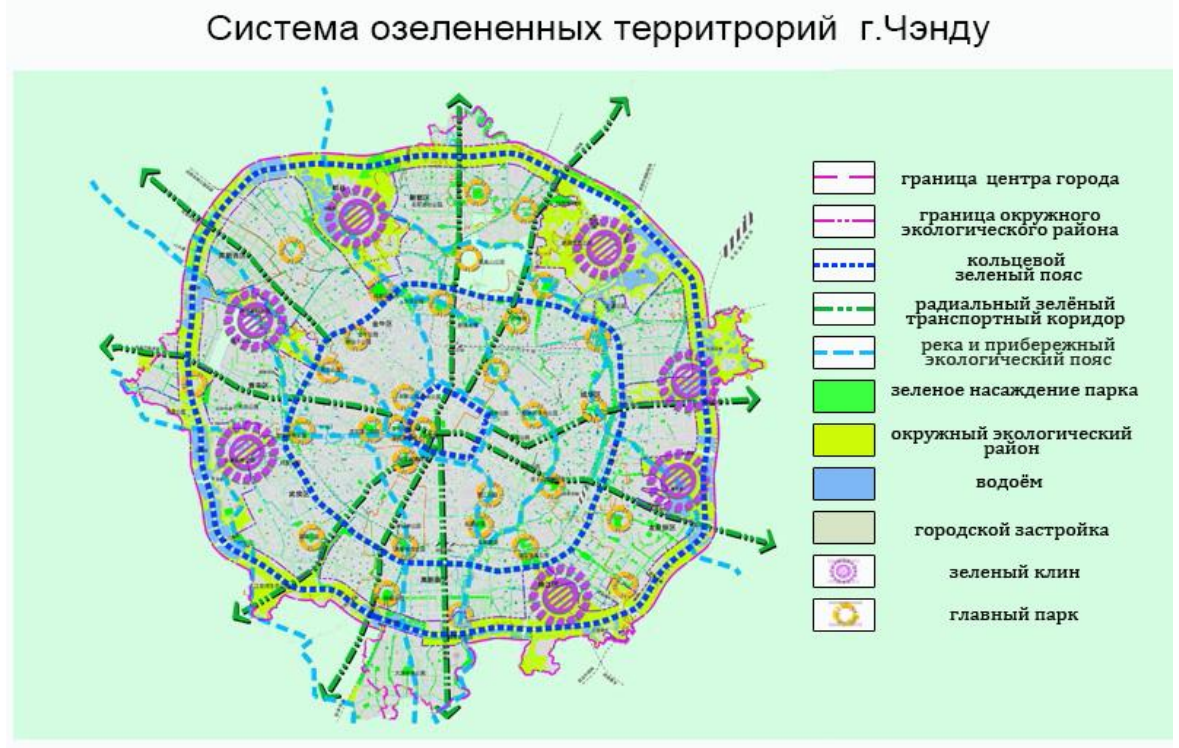

Рис. 1. Система озелененных территорий г. Чэнду

Планировочная структура Чэнду может быть охарактеризована как кольцевая-радиальная, и в сравнении близка к г. Москве. Структура зеленых территорий представлена зелеными клиньями и экологическим районом, расположенным по периметру города вдоль кольцевой автомобильной дороги Чэнду (ЧКАД) (рис. 1).

На основе данных генерального плана г. Чэнду нами была построена карта-схема распределения плотности населения на территории города (рис.2).

Анализ полученных данных показывает:

средняя плотность населения в центре города составляет 11482чел./км2;

плотность населения юго-западного района достиг 14454чел./ км 2, что выше плотности населения в северном районе;

самая высокая плотность в центральных районах, где плотность населения превышает 35000/km2.

Такое распределение плотности населения, характеризующееся её снижением по мере удаления от центра, характерно для многих городов: Париж, Берлин; Лондон, Нью Йорк, Джакарта. В таблице 1 приведены характеристики этих городов, полученные по данным автора и [1]. 


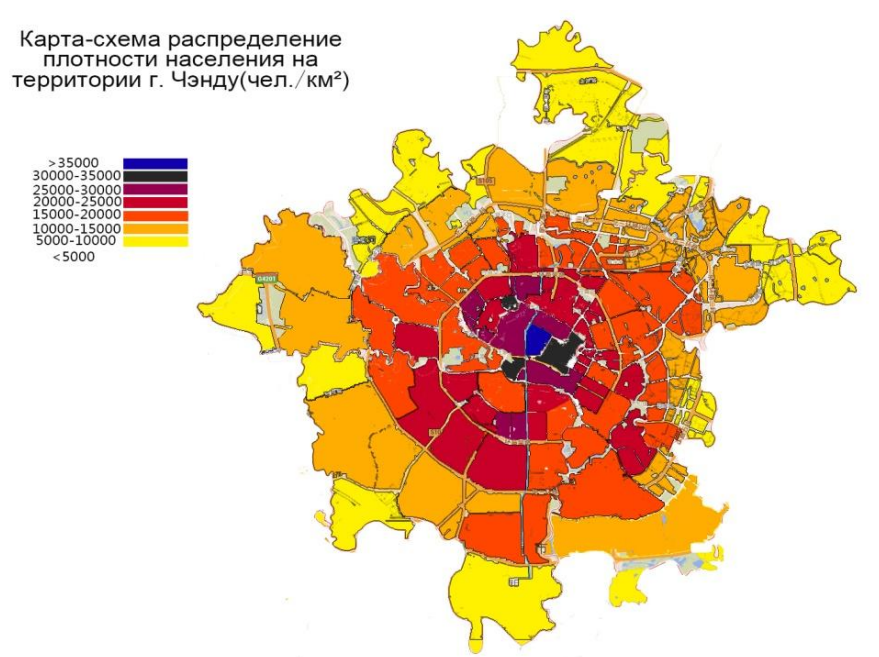

Рис. 1. Система озелененных территорий г.Чэнду

Таблица 1.

Характеристики городов.

\begin{tabular}{|c|c|c|c|}
\hline Город & $\begin{array}{c}\text { Численность } \\
\text { населения, } \\
\text { человек }\end{array}$ & $\begin{array}{c}\text { Площадь } \\
\text { территории } \\
\text { города, км }\end{array}$ & $\begin{array}{c}\text { Средняя } \\
\text { плотность } \\
\text { жителей, } \\
\text { чел/км }\end{array}$ \\
\hline Париж & 7877000 & 893 & 8820 \\
\hline Берлин & 4212000 & 1176 & 3581 \\
\hline Лондон & 6626000 & 1062 & 6239 \\
\hline Нью Йорк & 10752000 & 2674 & 4020 \\
\hline Джакарта & 14908000 & 2942 & 5067 \\
\hline Чэнду & 5349700 & 465,88 & 11482 \\
\hline
\end{tabular}

Анализ распределения зеленых территорий в городе показывае, что в центральных районах города Чэнду, характеризующихся самой высокой плотностью, площадь зеленых насаждений приблизительно равна 14417,75 га, что составляет 36,1 \% от общей площади города. Следует отметить, что в Китае площадь зеленых насаждений парков, скверов и других озелененных территорий определяется без учета земельных участков, выделенных под объекты социально-бытового обслуживания населения (кафе, туалеты, дорожки и др.).

В центре города Чэнду отсутствуют большие площади зеленых территорий, даже национального парка нет, только отдельные парки, расположенные в различных районах города. Это объясняется высокой стоимостью земли в центральных районах, которая способствует повышению плотности застройки и вытеснению зеленых территорий. 
Сопоставление рис. 1 и рис. 2, позволяет легко найти связь между плотностью населения и зелеными насаждениями, которая показывает, что повышение концентрация населения, вызывает уменьшение площади зелёных насаждений.

Особого внимания заслуживает территория окружного экологического района, расположенного во внешнем кольце Чэнду. Этот район характеризуется низкой плотностью населения, что позволяет создать и сохранять зеленый пояс с зелеными клиньями. Зеленый пояс имеет ширину в 500 метров, расположен по обе стороны кольцевой автомобильной дороги Чэнду и обеспечивает связь с зелеными клиньями, образуя единую природную систему (природный каркас) города. Площадь этого района около 187,15 км2, длина зеленого пояса превышает 85 км. В экологическом районе расположены леса, природные водные объекты, парки особо охраняемые природные территории, немногочисленные питомники, научно-исследовательские учреждений и объекты лесного сервиса (рис.3).

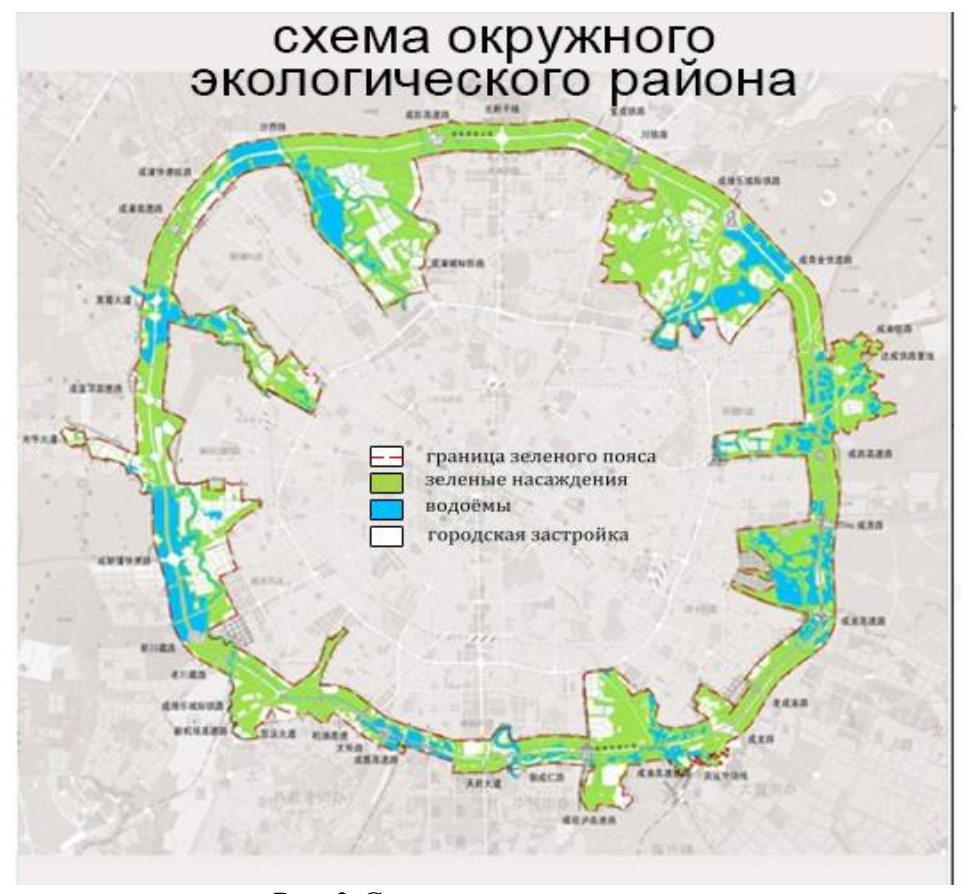

Рис 3.Схема экологического района

Сохранение этого района стало возможным благодаря эффективному региональному управлению, регулирующему плотность населения этого района, 
которая остается на сравнительном низком уровне. Региональное управление делится на 2 часть, включает:

1. Функциональное зонирование этого района на две территории. Первый зеленый пояс, размером приблизительно 200 метров шириной по обе стороны ЧКАД, в котором запрещена застройка и размещение капитальных сооружение в любой форме.

2. Буферный район экологического пояса (200-500 метров шириной по обе стороны ЧКАДа). В нем разрешается ограниченное строительство нежилые объектов, высотой не более 15м.

3. Постоянный мониторинг и строгий контроль.

\section{Выводы}

Плотность населения влияет на устойчивость природных экосистем. Чем выше концентрация населения на границах с озелененными территориями, тем больше антропогенное воздействие (рекреационная нагрузка) на природные экосистемы, что приводит к их деградации.

Размещение буферных зон около экологического района позволяет снизить плотность населения на границе озеленения. Вследствие этого, территория зеленого пояса защищена от прямого антропогенного воздействия, связанного с загрязнением воздуха, воды, применения пестицидов и минеральных удобрений.

Для обеспечения устойчивости природных экосистем необходимо в генеральных планах городов предусматривать размещение функциональных зон (жилых зон) с низким показателем плотности населения. 


\section{Литература:}

1. Alain Bertaud and Stephen Malpezzi The Spatial Distribution of Population in 48 World Cities: Implications for Economies in Transition. December 17, 2003. Comments Welcome. 92 c.

2. Краснощекова Н.С. Формирование природного каркаса в генеральных планах городов, Издательство «Архитектура-С», 2010.

3. Sherbina E.V., Danilina N.V. Vlasov D.N. City planning issues for sustainable development /International Journal of Applied Engineering Research ISSN 0973-4562 Volume 10, Number 22 (2015), pp 43131-43138 (C) Research India Publications. http://www.ripublication.com

4. Wang Yong-hua, теория окружного зеленого пояса и экологическое восстановление, ссылка на интернет источник (http://www.cnki.net/KCMS/detail/detail.aspx?dbname=cjfd2004\&filename =fjyl200453008) (на китайском языке)

5. Слепнев М.А., Щербина Е.В. Методические подходы к подготовке документации по регулированию режима содержания особо охраняемых природных территорий // Экология урбанизированных территорий. 2015. №3, С. 68-73.

6. Генеральный план г.Чэнду (2011г-2020г) (на китайском языке) ,ссылка на интернет источник (http://wenku.baidu.com/view/2c1bbda56529647d2728523a.html) китайском языке) 